\title{
Global Scientific Outputs of Palliative Care Publications: A Holistic Approach with Bibliometric Analysis
}

Arzu Akdağlı Ekici', [MD]

ORCID: 0000-0001-7219-3145

Özgür Yağan', [MD]

ORCID: 0000-0003-1596-1421

\section{sel) ABSTRACT Con}

Objective: This study aims to summarize the scientific outputs of the palliative care studies conducted between 1975 and 2019 through bibliometric analyses, identify the top effective journals, top-cited studies, the collaboration between countries, and trend topics.

Materials and Methods: We performed a bibliometric analysis on palliative care. "Palliative care", "terminal care", "end-of-life care" and "hospice care" terms were used as the keywords in the title section of articles in Web of Science database. Spearman correlation coefficient was performed for the correlation analysis between the number of publications produced by the countries and economic indicators.

Results: There were 22361 publications about palliative care. Of these publications, 10309 were articles. The top three countries that produced more than 100 articles were the USA, the United Kingdom, and Canada. The top three journals that had the highest number of publications were Journal of Palliative Medicine, Journal of Pain and Symptom Management, and Palliative Medicine. There was a positive, highly significant relationship between the number of publications and Gross domestic product $(r=0.709, p<0.001)$.

Conclusion: This study is believed to be a beneficial guide about the global outputs of palliative care for the clinicians and scientists and present new research ideas to the researchers.

Keywords: Palliative care, end-of-life care, hospice care, terminal care, bibliometric analysis.

https://doi.org/10.32552/2021.ActaMedica.999

Received: 2 December 2020, Accepted: 31 May 2021,

Published online: 20 June 2021

\section{INTRODUCTION}

Palliative care is defined as the supportive care provided to patients and their families who are facing a fatal condition in which the therapeutic approaches are insufficient [1-4]. The purpose of palliative care is to provide the patient with relief until the end-stage using pharmacological and nonpharmacological methods for preventing pain, dyspnea, and fatigue symptoms caused by the disease. The purpose of palliative care that starts with the diagnosis time and supportive care provided to the family in the mourning process is to relieve the pain of patients and families by making a comprehensive assessment of the physical, psychological and moral symptoms [1-4]. Just like pain affects the quality of life; anorexia, dysphagia, dyspnea, xerostomia, and weight loss are the most important symptoms that affect the course of the disease and have top priority in the treatment [5]. The main diseases that require palliative care include motor neuron diseases and progressive neurologic diseases (Alzheimer, ALS), advanced organ failure (heart, lung, kidney, liver, brain), cancers nonresponsive to the treatment, HIV/AIDS, and genetic/congenital, progressive diseases in children [5-6]. 
Bibliometrics is the statistical analysis of scientific publications, primarily articles [7-9]. Citation analysis as part of the bibliometric analysis is a method used for the relative effect of an article, author, or journal. Literature review becomes more and more difficult for researchers with the increasing number of publications [10-12]. Thanks to bibliometric analyses, researchers have access to a lot of summary information in a short time by obtaining the top-cited effective studies, related journals to be followed, the effectiveness of the countries, collaboration between the countries, and active authors and institutions [13-14].

The need for palliative care centers as well as the importance of these centers has been increasing due to factors such as an increase in cancers and longer length of life and an increase in chronic diseases [4]. However, the literature includes no bibliometric studies that provide a summary of the studies on palliative care. This study aims to summarize the scientific outputs of the studies conducted between 1975 and 2019 through bibliometric analyses, identify the top effective journals, top-cited studies, the collaboration between countries, and trend topics.

\section{MATERIALS and METHODS}

We performed a bibliometric analysis of the published literature between 1975 and 2019 on palliative care publications using Web of Science (WoS; Thomson Reuters, New York, NY, USA) database. "Palliative care", "terminal care", "end-oflife care" and "hospice care" terms were used as the keywords in the title section of articles (title: ("palliative care") or title: ("terminal care") or title: ("end-of-life care") or title: ("hospice care") refined by: document types: (article) timespan: 1975-2019. Indexes: SCl-Expanded, SSCl, A\&HCl, CPCl-S, CPCI$S S H, B K C I-S, B K C I-S S H, E S C l$.) The articles were downloaded from the WoS database (access date: 03.01.2020) and were analyzed bibliometrically. A web site (http://lert.co.nz/map/) was utilized for drawing the world map. Bibliometric network visualization was performed using the VOSviewer (Version 1.6.13) package programming [15]. Statistical analysis was performed using SPSS (Version 22.0, SPSS Inc., Chicago, IL, ABD) package programming. The normality of the data distribution was assessed using the Shapiro-Wilk test. Spearman correlation coefficient analysis was performed for the correlation analysis between the number of publications produced by the countries and economic indicators of GDP (gross domestic product) and GDP PPP (purchasing power parity). Estimations about the number of publications in the following years were done using the linear regression analysis. Statistical significance was taken $\mathrm{p}<0.05$.

\section{RESULTS}

A review of the related literature showed that there were 22361 publications about palliative care published between 1975 and 2019 (Article, proceedings paper, meeting abstract, review, letter, book review, editorial material, book, book chapter, bibliography, news item, etc.). Of these publications, 10309 were articles. Bibliometric analyses were performed with a total number of 10309 articles. $9580(92,9 \%)$ of the 10309 articles were written in English, and the remaining low number of articles were written in French (236), German (213), Spanish (161), Portuguese (42), Polish (19), Italian (15), Korean (10), Croatian (9), Turkish (5), Hungarian (4) Czech (3), Dutch (2), Greek (2), Japanese (2), Russian (2) Danish (1), Malay (1), Norwegian (1), and Slovenian (1) languages.

\section{Development of Publications}

The distribution of the publications according to years is demonstrated in Figure 1, which also demonstrates the regression analysis results about the estimations about the number of publications between 2020 and 2024. Regression analysis results showed that there would be 998 articles to be published in 2020 (Cl\%: 865-1131) and 1087 articles in 2024 (Cl\%: 898-1275) (Figure 1). There was a statistically significant increase trend in the publications $(p<0.05)$.

\section{Active Countries}

The distributions of the world countries that produced the highest number of publications are demonstrated in Figure 2. The top five countries that produced more than 100 articles were the USA (3953), the United Kingdom (1423), Canada (946), Australia (850), Germany (543), Netherlands (357), France (330), Japan (308), Spain (306), Italy (257), Sweden (232), Belgium (217), Switzerland (180), 


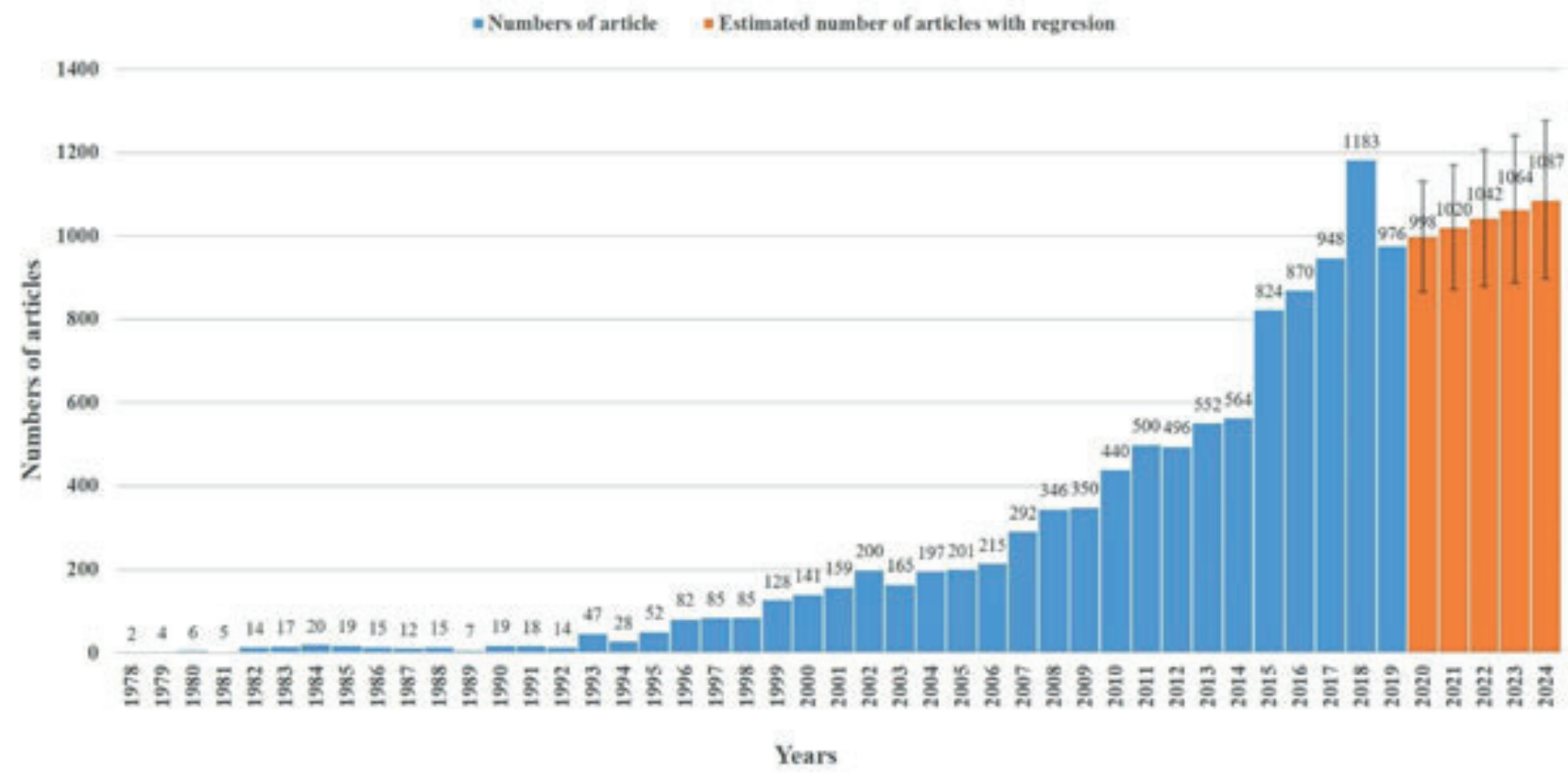

Figure 1. Distribution of articles by year on palliative care

Scotland (177), Taiwan (143), Ireland (140), Brazil (136), India (136), China (134), South Korea (134), Norway (116), and New Zealand (110) respectively. Figure 3 demonstrates the international collaboration network map of the 66 countries that produced at least 5 articles among 133 countries that had articles about palliative care. Cluster analysis results indicated 7 different collaborations in 7 different colors. palliative care and the total number of citations of these journals.

The top five journals that had the highest number of publications were Journal of Palliative Medicine (873), Journal of Pain and Symptom Management (793), Palliative Medicine (754), American Journal of Hospice Palliative Medicine (479), and Journal of Palliative Care (319) respectively.

\section{Active Organizations}

The top 10 active universities that had publications about this issue were King's College London (241),

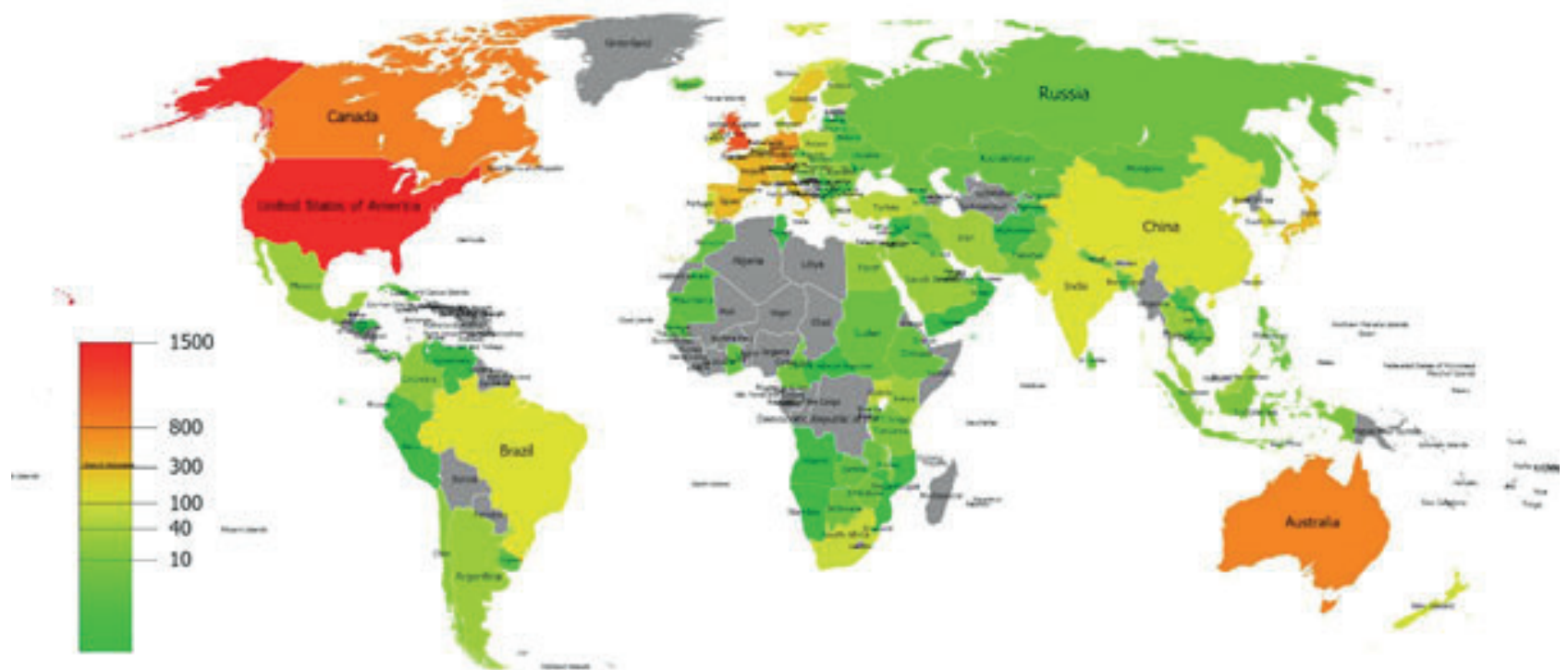

Figure 2. World map for the distribution of articles by country on palliative care.

Footnote: In the indicator given at the bottom left of the figure, productivity increases from green to red 


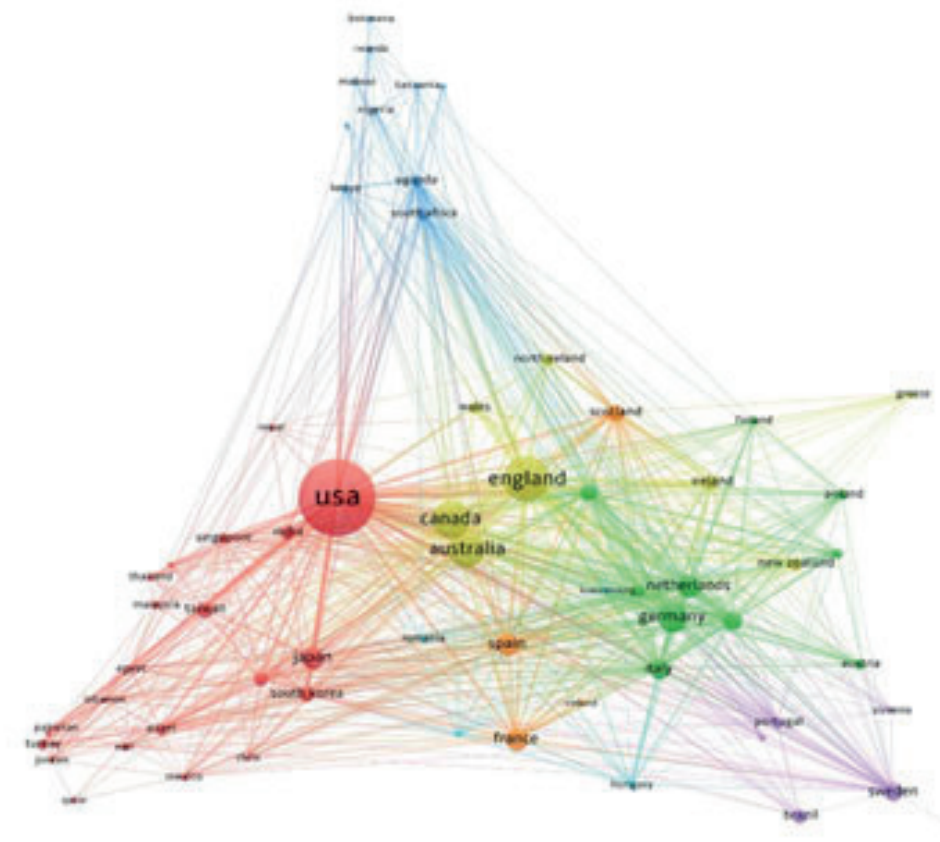

\section{A vosverever}

Figure 3. Network visualization map for international collaboration of worldwide countries on palliative care.

Footnote: The size of the circle shows the large number of articles, the colors indicate the clusters, and the thickness of the lines indicates the strength of relationship.

University Toronto (200), University Washington (189), Duke University (187), University of California, San Francisco (170), Flinders University South Australia (152), University Texas MD Anderson Cancer Center (147), University Pennsylvania (134), University Alberta (130), and Dana-Farber Cancer Institute (122) respectively.

\section{Active Authors}

The most active authors in this subject are; Bruera E (165), Higginson IJ (131), Morita T (97), Deliens L (95), Currow DC (94), Curtis JR (77), Radbruch L (75), Miyashita M (72), Payne S (68), and Harding R (64).

\section{Citation Analysis}

Table 2 demonstrates the bibliometric analysis of the top 15 articles that received most citations according to the total number of citations in the articles published between 1975 and 2019. The last column of Table 2 demonstrates the average number of citations per year.

The total number of citations per article was calculated by dividing the total number of citations received by the journals, and the network visualization map is demonstrated in Figure 4.

\section{Co-citation Analysis}

There were a total of 153676 publications cited in the references sections of all the articles that were analyzed. The top 5 articles that received the highest number of co-citations in the references section were the studies conducted by Temel et al. (2010), Connors et al. (1995), Bakitas et al. (2009), Bruera et al. (1991), and Teno et al. (2004) respectively [16-20].

\section{Trend Topics}

There were 9619 different keywords used in the 10309 articles. These words included 88 keywords that were used in at least 40 different articles. The cluster analysis between these keywords is given in Figure 5.a. Trend visualization network map is given in Figure 5.b. The most frequently used keywords about this issue are given in Table 3."

\section{Correlation Analysis}

There was a positive, highly significant relationship between the number of publications and GDP $(r=$ $0.709, p<0.001$ respectively). A positive, moderate level relationship was found between the number of publications and GDP PPP $(r=0.642, p<0.001)$. 
Table 1. Active journals on palliative care.

\begin{tabular}{|c|c|c|c|c|c|c|c|}
\hline Journals & $\mathrm{RC}$ & $\%$ & C & Journals & $\mathrm{RC}$ & $\%$ & $\mathrm{C}$ \\
\hline Journal of Palliative Medicine & 873 & 8.4 & 13432 & Clinics in Geriatric Medicine & 45 & 0.4 & 567 \\
\hline $\begin{array}{l}\text { Journal of Pain and Symptom } \\
\text { Management }\end{array}$ & 793 & 7.6 & 16140 & Critical Care Medicine & 44 & 0.4 & 2792 \\
\hline Palliative Medicine & 754 & 7.3 & 19061 & Social Science Medicine & 38 & 0.3 & 1072 \\
\hline $\begin{array}{l}\text { American Journal of Hospice Palliative } \\
\text { Medicine }\end{array}$ & 479 & 4.6 & 2672 & $\begin{array}{l}\text { JAMA Journal of the American } \\
\text { Medical Association }\end{array}$ & 37 & 0.3 & 5756 \\
\hline Journal of Palliative Care & 319 & 3.0 & 4065 & Pediatrics & 36 & 0.3 & 2730 \\
\hline BMC Palliative Care & 301 & 2.9 & 2043 & Cancer Nursing & 35 & 0.3 & 480 \\
\hline Supportive Care in Cancer & 260 & 2.5 & 4025 & Nursing Ethics & 35 & 0.3 & 222 \\
\hline Journal of Hospice Palliative Nursing & 211 & 2.0 & 823 & British Medical Journal & 33 & 0.3 & 1454 \\
\hline Palliative Supportive Care & 159 & 1.5 & 1083 & BMJ Open & 32 & 0. & 292 \\
\hline BMJ Supportive Palliative Care & 105 & 1.0 & 522 & Journal of Oncology Practice & 30 & 0.2 & 317 \\
\hline Medecine Palliative & 101 & 0.9 & 51 & Patient Education and Counseling & 30 & 0.2 & 366 \\
\hline International Journal of Palliative Nursing & 97 & 0.9 & 200 & $\begin{array}{l}\text { Journal of the American Medical } \\
\text { Directors Association }\end{array}$ & 29 & 0.2 & 452 \\
\hline Indian Journal of Palliative Care & 91 & 0.8 & 160 & Canadian Family Physician & 28 & 0.2 & 216 \\
\hline Journal of the American Geriatrics Society & 86 & 0.8 & 3806 & Clinical Journal of Oncology Nursing & 28 & 0.2 & 170 \\
\hline Medicina Paliativa & 74 & 0.7 & 87 & Schmerz & 28 & 0.2 & 190 \\
\hline Journal of Advanced Nursing & 64 & 0.6 & 1808 & Health Social Care in the Community & 27 & 0.2 & 471 \\
\hline Journal of Clinical Nursing & 57 & 0.5 & 632 & Journal of Medical Ethics & 27 & 0.2 & 421 \\
\hline Plos One & 57 & 0.5 & 482 & $\begin{array}{l}\text { Journal of Social Work in End of Life } \\
\text { Palliative Care }\end{array}$ & 27 & 0.2 & 71 \\
\hline Journal of Clinical Oncology & 55 & 0.5 & 5347 & Oncologist & 27 & 0.2 & 560 \\
\hline Cancer & 53 & 0.5 & 2444 & Zeitschrift Fur Palliativmedizin & 27 & 0.2 & 19 \\
\hline Annals of Palliative Medicine & 51 & 0.4 & 207 & BMC Health Services Research & 26 & 0.2 & 461 \\
\hline Progress in Palliative Care & 50 & 0.4 & 66 & British Journal of General Practice & 26 & 0.2 & 801 \\
\hline Omega Journal of Death And Dying & 47 & 0.4 & 284 & European Journal of Cancer & 26 & 0.2 & 1123 \\
\hline European Journal of Cancer Care & 46 & 0.4 & 702 & Nurse Education Today & 26 & 0.2 & 267 \\
\hline Psycho Oncology & 46 & 0.4 & 787 & Archives De Pediatrie & 25 & 0.2 & 108 \\
\hline
\end{tabular}

RC: Record Count C: Number of Citation

\section{DISCUSSION}

The findings showed that there was a significant increase trend in the articles about palliative care. The number of articles low at the beginning started to increase after the year 2006 with more than 200 articles published, and there have been more than 800 articles published every year since 2015. Regression analysis results also indicated that the increase trend would continue. An analysis of the publication distributions of the world countries showed that the developed countries were effective in publication productivity. Several studies in literature reported that the economic growth of the countries was related to their article productivity [9-11]. In their bibliometric study on Palliative Care, Liu et al. (2018) also reported that there was a highly significant relationship between the economic power of the countries and their publication productivity [21]. An analysis of the authorship collaboration of the countries showed that geographical regional neighborhood was the most important factor in collaborations. The topproductive countries such as the United Kingdom, Canada, and Australia were in the same cluster, which shows that collaborations and co-research are important factors for scientific outputs.

An assessment of the articles analyzed according to the number of citations showed that the study that received the highest number of citations in total and per year was the study entitled "Early palliative care for patients with metastatic nonsmall-cell lung cancer" written by Temel, JS. et al. and published in the New England Journal of 


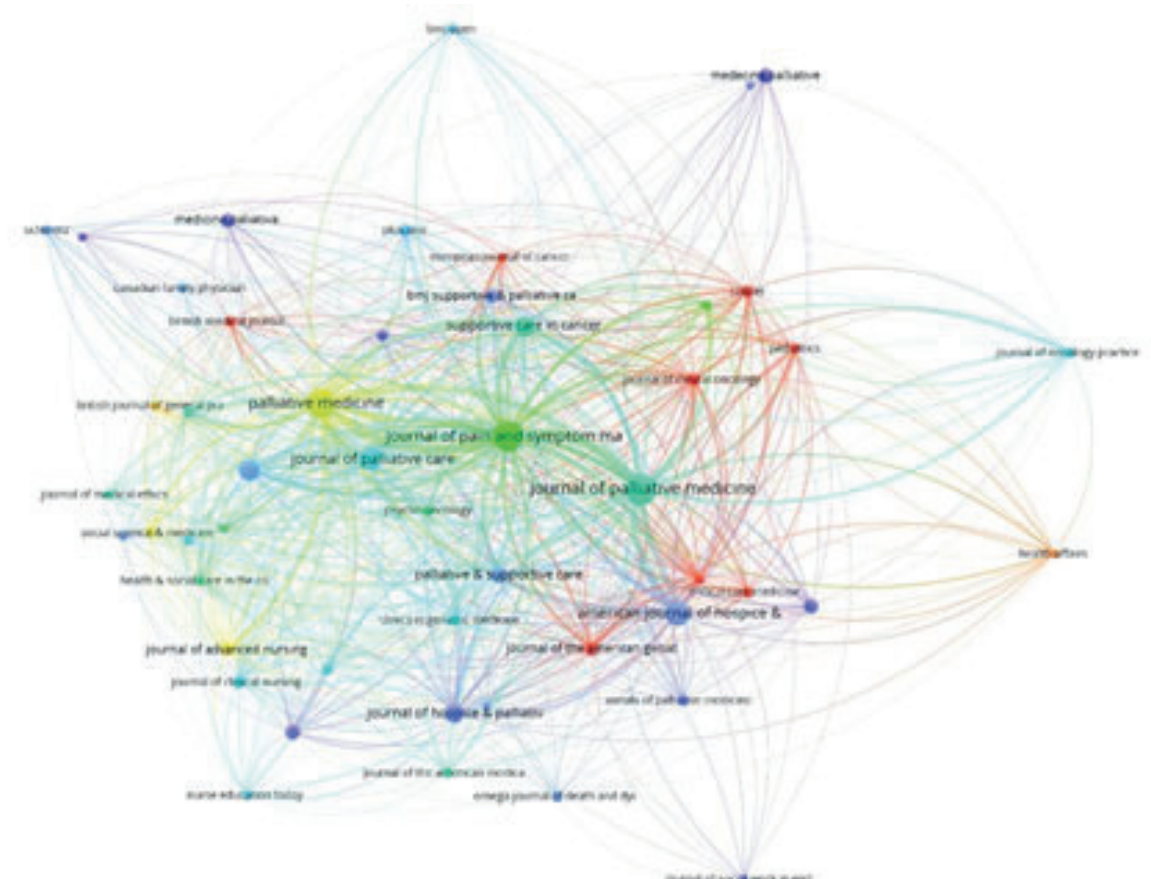

Avosverem

Figure 4. Network visualization map of journals based on citations analysis on palliative care

Footnote: The number of citations from blue to red (blue-green-yellow-red) increases
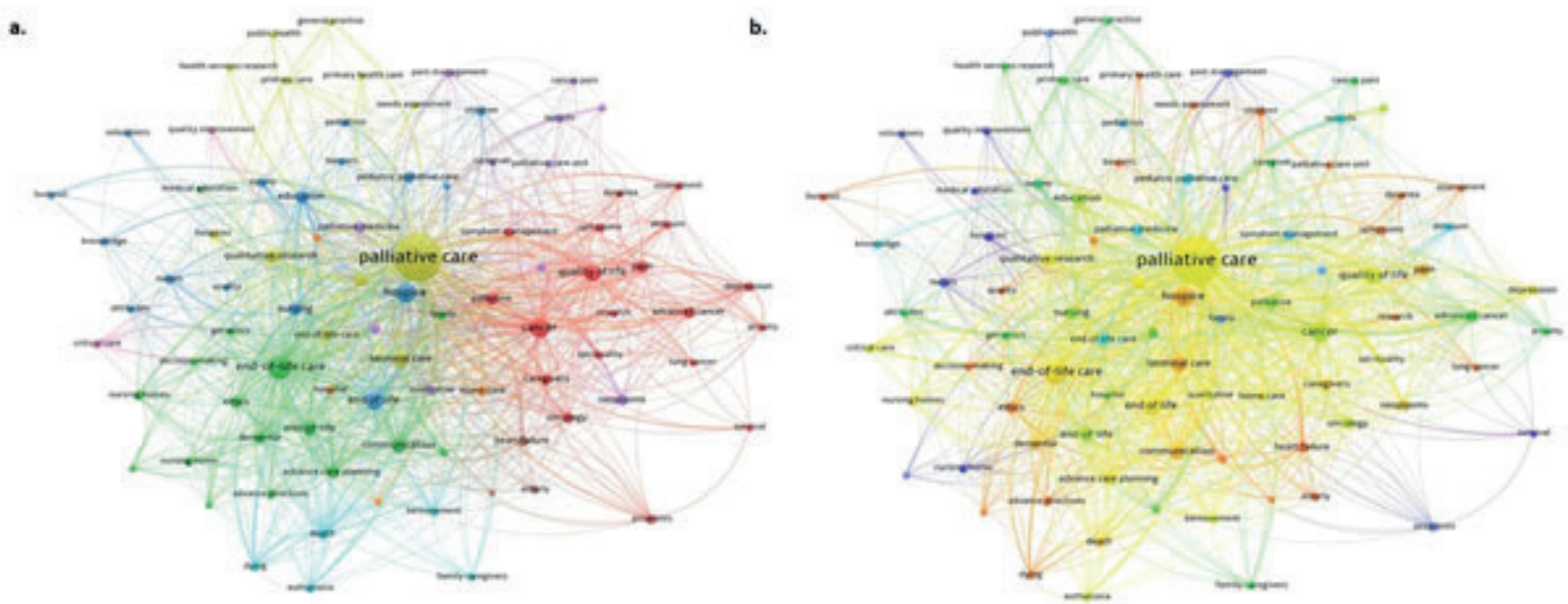

Figure 5. a. Network visualization map for cluster analysis based on keyword analysis on palliative care Footnote: Indicator shows current publications from blue to red $\mathbf{b}$. Network visualization map for trends based on keyword analysis on palliative care

Footnote: Indicator shows current publications from blue to red

Medicine in 2010 [16]. The top effective study according to the total number of citations was the study conducted by Detering, KM. et al., which was entitled "The impact of advance care planning on end of life care in elderly patients: randomized controlled trial" published in BMJ-British Medical Journal in 2010 [22]. The third top-cited study was conducted by Teno et al. [20].
An assessment done according to the number of average citations per year showed that the top effective article, which was not among the top 10, was written by Ferrell et al. (2017) and published in the Journal of Clinical Oncology with the title of "Integration of palliative care into standard oncology care: American Society of Clinical Oncology clinical practice guideline update" [23]. 
Table 2. Top 15 most cited articles according to total citations on palliative care.

\begin{tabular}{|c|c|c|c|c|c|c|}
\hline No & Article & Author & Journal & PY & TC & $A C$ \\
\hline 1 & $\begin{array}{l}\text { Early palliative care for patients with metastatic non- } \\
\text { small-cell lung cancer }\end{array}$ & Temel, JS. et al. & $\begin{array}{l}\text { New England Journal of } \\
\text { Medicine }\end{array}$ & 2010 & 3237 & 323.7 \\
\hline 2 & $\begin{array}{l}\text { The impact of advance care planning on end of life } \\
\text { care in elderly patients: randomised controlled trial }\end{array}$ & $\begin{array}{l}\text { Detering, KM. } \\
\text { et al. }\end{array}$ & $\begin{array}{l}\text { BMJ-British Medical } \\
\text { Journal }\end{array}$ & 2010 & 919 & 91.9 \\
\hline 3 & $\begin{array}{l}\text { Family perspectives on end-of-life care at the last } \\
\text { place of care }\end{array}$ & Teno, JM. et al. & $\begin{array}{l}\text { Jama-Journal of the } \\
\text { American Medical } \\
\text { Association }\end{array}$ & 2004 & 909 & 56.81 \\
\hline 4 & $\begin{array}{l}\text { Prevalence of depression, anxiety, and adjustment } \\
\text { disorder in oncological, haematological, and palliative- } \\
\text { care settings: a meta-analysis of } 94 \text { interview-based } \\
\text { studies }\end{array}$ & $\begin{array}{l}\text { Mitchell, AJ. } \\
\text { et al. }\end{array}$ & Lancet Oncology & 2011 & 778 & 86.44 \\
\hline 5 & $\begin{array}{l}\text { Effects of a palliative care intervention on clinical } \\
\text { outcomes in patients with advanced cancer the } \\
\text { project enable ii randomized controlled trial }\end{array}$ & Bakitas, M. et al. & $\begin{array}{l}\text { Jama-Journal of the } \\
\text { American Medical } \\
\text { Association }\end{array}$ & 2009 & 770 & 70 \\
\hline 6 & Quality end-of-life care - patients' perspectives & Singer, PA. et al. & $\begin{array}{l}\text { Jama-Journal of the } \\
\text { American Medical } \\
\text { Association }\end{array}$ & 1999 & 734 & 34.95 \\
\hline 7 & $\begin{array}{l}\text { American society of clinical oncology provisional } \\
\text { clinical opinion: the integration of palliative care into } \\
\text { standard oncology care }\end{array}$ & Smith, TJ. et al. & $\begin{array}{l}\text { Journal of Clinical } \\
\text { Oncology }\end{array}$ & 2012 & 715 & 89.38 \\
\hline 8 & $\begin{array}{l}\text { Early palliative care for patients with advanced cancer: } \\
\text { a cluster-randomised controlled trial }\end{array}$ & $\begin{array}{l}\text { Zimmermann, C. } \\
\text { et al. }\end{array}$ & Lancet & 2014 & 587 & 97.83 \\
\hline 9 & $\begin{array}{l}\text { Change in end-of-life care for medicare beneficiaries } \\
\text { site of death, place of care, and health care transitions } \\
\text { in } 2000,2005 \text {, and } 2009\end{array}$ & Teno, JM. et al. & $\begin{array}{l}\text { Jama-Journal of the } \\
\text { American Medical } \\
\text { Association }\end{array}$ & 2013 & 552 & 78.86 \\
\hline 10 & $\begin{array}{l}\text { Palliative care: the world health organization's global } \\
\text { perspective }\end{array}$ & $\begin{array}{l}\text { Sepulveda, C. } \\
\text { et al. }\end{array}$ & $\begin{array}{l}\text { Journal of Pain and } \\
\text { Symptom Management }\end{array}$ & 2002 & 512 & 28.44 \\
\hline 11 & $\begin{array}{l}\text { Improving the quality of spiritual care as a dimension } \\
\text { of palliative care: the report of the consensus } \\
\text { conference }\end{array}$ & $\begin{array}{l}\text { Puchalski, C. } \\
\text { et al. }\end{array}$ & $\begin{array}{l}\text { Journal of Palliative } \\
\text { Medicine }\end{array}$ & 2009 & 506 & 46 \\
\hline 12 & Palliative care for children & Nelson, RM. et al. & Pediatrics & 2000 & 505 & 25.25 \\
\hline 13 & $\begin{array}{l}\text { Cost savings associated with us hospital palliative care } \\
\text { consultation programs }\end{array}$ & $\begin{array}{l}\text { Morrison, RS. } \\
\text { et al. }\end{array}$ & $\begin{array}{l}\text { Archives of Internal } \\
\text { Medicine }\end{array}$ & 2008 & 453 & 37.75 \\
\hline 14 & $\begin{array}{l}\text { Increased satisfaction with care and lower costs: } \\
\text { results of a randomized trial of in-home palliative care }\end{array}$ & Brumley, R. et al. & $\begin{array}{l}\text { Journal of the American } \\
\text { Geriatrics Society }\end{array}$ & 2007 & 440 & 33.85 \\
\hline 15 & $\begin{array}{l}\text { A national survey of end-of-life care for critically ill } \\
\text { patients }\end{array}$ & $\begin{array}{l}\text { Prendergast, TJ. } \\
\text { et al. }\end{array}$ & $\begin{array}{l}\text { American Journal of } \\
\text { Respiratory and Critical } \\
\text { Care Medicine }\end{array}$ & 1998 & 430 & 19.55 \\
\hline
\end{tabular}

PY: Publication year, TC: Total citation, AC: Average citations per year

The second top effective study following this one was conducted by Zimmermann et al. (2014) and published in Lancet Journal with the title of "Early palliative care for patients with advanced cancer: a cluster-randomized controlled trial" [24]. The third most effective study according to the average number of citations per year was written by Smith et al. (2012) with the title of "American Society of Clinical Oncology provisional clinical opinion: the integration of palliative care into standard oncology care" [25]. This study was followed by the metaanalysis study conducted by Mitchell et al. (2011) on depression, anxiety, and adjustment disorder prevalence in cancer patients. The study was also ranked fourth according to the total number of citations [26].

As to the number of co-citations in all the articles that were analyzed, the studies conducted by Temel et al. (2010), Connors et al. (1995), Bakitas et al. (2009), Bruera et al. (1991) and Teno et al. (2004) were the top-cited studies [16-20]. Researchers interested in this topic could be recommended to read the above-mentioned publications first. 
Table 3. The most used frequently keywords on palliative care.

\begin{tabular}{|c|c|c|c|c|c|c|c|}
\hline Keyword & $\mathrm{O}$ & Keyword & $\mathrm{O}$ & Keyword & O & Keyword & $\mathrm{O}$ \\
\hline palliative care & 4553 & $\begin{array}{l}\text { pediatric palliative } \\
\text { care }\end{array}$ & 119 & pain management & 70 & needs assessment & 48 \\
\hline end-of-life care & 809 & palliative medicine & 118 & children & 69 & research & 48 \\
\hline cancer & 513 & death & 112 & nursing home & 69 & death and dying & 47 \\
\hline hospice & 501 & heart failure & 110 & hospices & 68 & geriatrics & 47 \\
\hline end of life & 415 & caregivers & 102 & opioids & 68 & long-term care & 47 \\
\hline quality of life & 355 & home care & 98 & qualitative & 67 & primary care & 47 \\
\hline terminal care & 276 & quality of care & 96 & quality improvement & 66 & quality & 47 \\
\hline communication & 262 & depression & 95 & spirituality & 66 & attitudes & 46 \\
\hline end-of-life & 233 & nursing homes & 89 & symptom control & 65 & cancer pain & 46 \\
\hline qualitative research & 233 & nurses & 88 & delirium & 60 & general practice & 46 \\
\hline education & 187 & $\begin{array}{l}\text { symptom } \\
\text { management }\end{array}$ & 86 & evaluation & 59 & palliative care unit & 46 \\
\hline pain & 182 & survey & 83 & knowledge & 59 & place of death & 46 \\
\hline nursing & 175 & family & 81 & assessment & 56 & decision-making & 45 \\
\hline hospice care & 170 & supportive care & 80 & elderly & 56 & medical education & 45 \\
\hline advance care planning & 164 & bereavement & 79 & hospital & 55 & volunteers & 45 \\
\hline palliative & 164 & euthanasia & 76 & pediatrics & 54 & anxiety & 44 \\
\hline advanced cancer & 142 & decision making & 75 & barriers & 53 & caregiver & 44 \\
\hline dementia & 134 & dying & 73 & lung cancer & 52 & family caregivers & 43 \\
\hline neoplasms & 134 & symptoms & 73 & pediatric & 52 & survival & 43 \\
\hline ethics & 132 & advance directives & 72 & burnout & 50 & health services & 42 \\
\hline end of life care & 130 & prognosis & 72 & public health & 50 & dyspnea & 41 \\
\hline oncology & 126 & critical care & 71 & $\begin{array}{l}\text { health services } \\
\text { research }\end{array}$ & 48 & primary health care & 40 \\
\hline
\end{tabular}

O: Number of occurrences

The top active journals that produced more than 200 publications were Journal of Palliative Medicine, Journal of Pain, and Symptom Management Palliative Medicine, American Journal of Hospice Palliative Medicine, Journal of Palliative Care, BMC Palliative Care, Supportive Care in Cancer, and Journal of Hospice Palliative Nursing respectively. Authors who would like to produce publications in this issue could consider these journals. An assessment of the journals that produced 25 and more articles according to the number of citations per article showed that the JAMA Journal of the American Medical Association and Journal of Clinical Oncology, Pediatrics, Critical Care Medicine, Cancer, Journal of the American Geriatrics Society, British Medical Journal, European Journal of Cancer, British Journal of General Practice, Journal of Advanced Nursing, Social Science Medicine, Palliative Medicine, Oncologist, and Journal of Pain and Symptom Management were listed at the top respectively. Researchers who would like to have more impact on their articles could consider these journals.

According to the keyword trend analysis results, the keywords studied in recent years were quality, primary health care, decision-making, barriers, children, needs assessment, dyspnea, symptoms, lung cancer, heart failure, ethics, advance directives, burnout, death, and dying.

A literature review indicated only 3 bibliometric studies on palliative care. Cheong et al. (2019) published a bibliometric study on palliative care studies in the Asian Pacific Region [27]. de Andrade et al. (2016) also conducted a bibliometric study on Palliative Care and Spirituality [28]. Liu et al. (2018) conducted a bibliometric study with 6273 articles on palliative care studies between 2001 and 2016 [21]. The present study is more comprehensive than these studies mentioned. Firstly, it encompasses a wider interval in terms of the years when the articles were published. This study is the most comprehensive one in the literature that analyzed 
more than 10 thousand articles published between the years 1975 and 2019. In addition, unlike other studies, this study is the first study that includes keyword analysis as well as citation analysis for journals and articles.

A limitation of this study is that it did not utilize databases such as PubMed, Google Scholar, and Scopus because the WoS database indexes articles published in the journals with higher impact in comparison to other databases. In addition, since the WoS index enables no access to the publications before 1975, we could not analyze the publications before 1975 .

As a result, there was a statistically significant increase trend in the number of publications about palliative care. The most productive countries were the USA, United Kingdom, Canada, and Australia. Publication productivity was affected by the economic growth of the countries. This article provides a comprehensive bibliometric summary of the 10309 articles on palliative care published between 1975 and 2019. This study revealed the effective journals that produced publications about this issue, effective articles that received more citations, and trend topics. This article is believed to be a beneficial guide about the global outputs of palliative care for the clinicians and scientists and present new research ideas to the researchers.

\section{CONFLICT of INTEREST}

Authors declares that they have no conflict of interest.

\section{ree REFERENCES Ceen}

[1] Stjernswärd J, Foley KM, Ferris FD. The public health strategy for palliative care. Journal of Pain and Symptom Management 2007; 33(5): 486-493.

[2] Arias-Casais N, Garralda E, López-Fidalgo J. et al. Consensus Building on Health Indicators to Assess PC Global Development with an International Group of Experts. Journal of Pain and Symptom Management 2019; 58(3): 445-453.

[3] Committee on Bioethics. Palliative care for children. Pediatrics 2000; 106(2): 351-357.

[4] Kıvanç MM. Palliative Care Services in Turkey. Journal of Health Science and Profession 2017; 4(2): 132-135.

[5] KabalakAA, ÖztürkH, Çağıl H. End of Life Care Organization; Palliative Care. The Journal of Intensive Care Medicine 2013; 11(2): 56-70.

[6] Borasio GD. Translating the World Health Organization definition of palliative care into scientific practice. Palliat Support Care 2011; 9: 1-2.

[7] Demir E. The evolution of spirituality, religion and health publications: Yesterday, today and tomorrow. J Relig Health 2019; 58(1): 1-13.

[8] Doğan G, İpek H. The Development of Necrotizing Enterocolitis Publications: A Holistic Evolution of Global Literature with Bibliometric Analysis. Eur J Pediatr Surg. 2019; 30: 293-303.

[9] Demir E, Comba A. The Evolution of Celiac Disease Publications: A Holistic Approach with Bibliometric Analysis. Ir J Med Sci. 2020; 189(1): 267-276.

[10] Doğan G, Kayır S. Global Scientific Outputs of Brain Death Publications and Evaluation According to the Religions of Countries, J Relig Health 2020; 59(1): 96-112.
[11] Demir E, Yaşar E, Özkoçak V. et al. The evolution of the field of legal medicine: A holistic investigation of global outputs with bibliometric analysis. J Forensic Leg Med. 2020; 69: 101885.

[12] Muslu Ü. Demir E. Development of rhinoplasty: yesterday and today. Medical Science 2019; 23(97): 294-301.

[13] Demir E, Akmeşe ÖF, Erbay H. et al. Bibliometric analysis of publications on house dust mites during 1980-2018. Allergologia et Immunopathologia 2020; 48(4): 374-383.

[14] Kiraz M. Demir E. A Bibliometric analysis of publications on Spinal Cord injury during 1980-2018. World Neurosurgery 2020; 136: 504-513.

[15] Van Eck NJ, Waltman, L. Software survey: VOSviewer, a computer program for bibliometric mapping. Scientometrics 2010; 84(2): 523-538.

[16] Temel JS, Greer JA, Muzikansky A. et al. Early palliative care for patients with metastatic non-small-cell lung cancer. New England Journal of Medicine 2010; 363(8): 733-742.

[17] Connors AF, Dawson NV, Desbiens NA. et al. A controlled trial to improve care for seriously ill hospitalized patients: The study to understand prognoses and preferences for outcomes and risks of treatments (SUPPORT). Jama 1995; 274(20): 1591-1598.

[18] Bakitas M, Lyons KD, Hegel MT. et al. Effects of a palliative care intervention on clinical outcomes in patients with advanced cancer: The Project ENABLE II randomized controlled trial. Jama 2009; 302(7): 741-749.

[19] Bruera E, Kuehn N, Miller MJ. et al. The Edmonton Symptom Assessment System (ESAS): a simple method for the assessment of palliative care patients. Journal of Palliative Care 1991; 7(2): 6-9. 
[20] Teno JM, Clarridge BR, Casey V. et al. Family perspectives on end-of-life care at the last place of care. Jama 2004; 291(1): 88-93.

[21] Liu CJ, Yeh TC, Hsu SH. et al. Bibliometric Analysis of Palliative Care-Related Publication Trends During 2001 to 2016. American Journal of Hospice and Palliative Medicine 2018; 35(10): 1280-1286.

[22] Detering KM, Hancock AD, Reade MC. et al. The impact of advance care planning on end of life care in elderly patients: randomised controlled trial. Bmj, 2010; 340: 1345.

[23] Ferrell BR, Temel JS, Temin S. et al. Integration of palliative care into standard oncology care: American Society of Clinical Oncology clinical practice guideline update. J Clin Oncol, 2017; 35(1): 96-112.

[24] Zimmermann C, Swami N, Krzyzanowska M. et al. Early palliative care for patients with advanced cancer: a clusterrandomised controlled trial. The Lancet 2014; 383(9930): 1721-1730.
[25] Smith TJ, Temin S, Alesi ER. et al. American Society of Clinical Oncology provisional clinical opinion: the integration of palliative care into standard oncology care. Journal of Clinical Oncology 2012; 30(8): 880-887.

[26] Mitchell AJ, Chan M, Bhatti $H$. et al. Prevalence of depression, anxiety, and adjustment disorder in oncological, haematological, and palliative-care settings: a meta-analysis of 94 interview-based studies. The Lancet Oncology 2011; 12(2): 160-174.

[27] Cheong WL, Mohan D, Warren N. et al. Palliative care research in the Asia Pacific Region: a systematic review and bibliometric analysis of peer-reviewed publications. Journal of Palliative Medicine 2019; 22(5): 545-552.

[28] de Andrade ACC, da Costa SFG, Zaccara AAL. et al. Palliative Care and Spirituality: Bibliometric Research in Health Field. International Archives of Medicine 2016; 8. 